\title{
Simulation of defoliation caused by Black Sigatoka in the yield and quality of banana 'Nanica' fruits
}

\author{
Juliana Domingues Lima ${ }^{1^{*}}$ Jessica Andrade Florencio ${ }^{1}$ Wilson da Silva Moraes ${ }^{2}$ \\ Silvia Helena Modenese Gorla da Silva ${ }^{1}$ Danilo Eduardo Rozane ${ }^{1}$ Eduardo Nardini Gomes $^{1}$
}

\footnotetext{
${ }^{1}$ Universidade Estadual Paulista “Júlio de Mesquita Filho” (UNESP), Campus Experimental de Registro, Rua Nélson Brihi Badur, 430, 11900-000, Registro, SP, Brasil. E-mail: judlima@registro.unesp.br. "Corresponding author.

${ }^{2}$ Agência Paulista de Tecnologia dos Agronegócios (APTA), Registro, SP, Brasil.
}

ABSTRACT: Defoliation caused by Black Sigatoka in yield and quality of banana 'Nanica' was stimulated in this study. A completely randomized $2 x 8$ factorial design with six repetitions was used, in which period of bunch formation and number of leaves at flowering were established as factors. Plants for defoliation were selected on 04/05/2013 (Period 1), and on 07/01/2014 (Period 2). Six to to 13 leaves remained per plant by removing those with more than 50\% of blade with injury or senescence. More appropriate climatic conditions before and after flowering, promoted greater mass accumulation in the bunch in Period 2. The increased number of leaves at flowering increased the length of the fruit and the mass of $4^{\text {th }}$ hand, as well as the bunch mass and postharvest period. Defoliation is suggested only for non-functional leaves as well as the maintenance of at least 10 leaves per plant, independent of the period of bunch formation.

Key words: Musa spp., bunch mass, fruit size, source/sink ratio.

\section{Simulação da desfolha causada pela Sigatoka Negra na produção e a qualidade de frutos da bananeira 'Nanica'}

\begin{abstract}
RESUMO: Simulou-se o efeito da desfolha causada pela Sigatoka Negra na produção e qualidade dos frutos da bananeira 'Nanica'. Adotouse o delineamento inteiramente casualizado, em esquema fatorial $2 x 8$, com seis repetições, no qual o período de formação do cacho e o número de folhas na floração foram estabelecidos como fatores. No Periodo 1, a seleção de plantas para desfolha foi realizada em 04/05/2013 e, no Período 2, em 07/01/2014. Mantiveram-se 6 a 13 folhas por planta, removendo as folhas com mais $50 \%$ do limbo com injúria ou senescência. Condições climáticas mais apropriadas antes e depois da floração promoveram maior acumulação de massa no cacho, no Período 2. O aumento do número de folhas na floração aumentou o comprimento do fruto e a massa da $4^{a}$ penca, bem como a massa do cacho e periodo pós-colheita. Sugere-se a desfolha apenas para folhas não-funcionais e a manutenção de pelo menos 10 folhas por planta, independente do periodo de formação do cacho.
\end{abstract}

Palavras-chave: Musa sp., massa do cacho, tamanho do fruto, relação fonte/dreno.

The growth and yield of banana depends on the maintenance of leaves until the complete development of the fruit. At flowering, the number of leaves is maximum and then decline with the natural senescence. Previous studies indicated a need of 5 (CHILLET et al., 2012), 7 (RAMÍREZ et al., 2008), 7 to 9 (VARGAS et al., 2009), 9-10 (DANIELLS et al., 1994), 12 (GONZÁLEZ et al., 2012) leaves to filling banana bunch cv. 'Grande Naine', which variation may be related to climate conditions and cultural practices.

In the Ribeira Valley, main producing region of banana of São Paulo State, defoliation is a cultural practice adopted for leaves with $50 \%$ of its area leaf taken by injuries caused by the Black Sigatoka, which helps to reduce fungal inoculum source (Mycosphaerella fijiensis) (MORAES et al., 2005). However, there is no regional information on their impact. Thus, the objective was to simulate the effect of defoliation on yield and fruit quality of banana 'Nanica' depending on the bunch formation period.

The experiment was conducted with banana plants (Musa sp. AAA group 'Nanica') in the fifth cycle of yield, cultivated at spacing $2.5 \times 2.5 \mathrm{~m}$, in Registro, SP (24 $28^{\prime} 17^{\prime} \mathrm{S}, 47^{\circ} 50^{\prime} 39^{\prime}$ ' W, $20 \mathrm{~m}$ asl), under humid tropical climate (Af) and soil type Cambisol. All cultural practices required for good production were adopted, including the chemical control of Black Sigatoka, according to MORAES et al. (2005). A completely randomized 2x8 factorial design with six repetitions was used, in which period of bunch formation and the number of leaves at flowering were established as factors. There was the selection of plants for defoliation in Period 1 on 04/05/2013, and in Period 2, 07/01/2014. Six to 13 leaves remained per 
plant by removing those with more than $50 \%$ of blade with injury or senescence. Bunches were harvested when the fruits from the last hand reached $30 \mathrm{~mm}$ in diameter. The number of hands, the weight of the bunch and the weight of the stalk were recorded. The $1^{\text {st }}, 4^{\text {th }}$ and last hands of the bunch were weighed and the number, mean diameter and length of the fruits present in each hand noted. The $4^{\text {th }}$ hand was kept at $25^{\circ} \mathrm{C}$ until they reached the commercial ripening. The fruit were evaluated in terms of: (a) postharvest period, time between harvest and complete maturity; (b) peel colour measured using a colorimeter; (c) firmness of pulp, estimated with texture analyzer; (d) total soluble solid, determined by using refractometer (TRESSLER \& JOSLYN, 1961); (e) pH and (f) determined using pH-meter (AOAC, 2005). Data was analysed by ANOVA (F-test) using the software Sisvar 4.2 and significance was considered at $5 \%(\mathrm{P}<0.05)$. For some variables, there was the study of regression and linear correlation by Pearson method.

Perimeter of the pseudo stem at flowering and harvest, bunch filling time, bunch mass and number of hands were higher in Period 1, while the mass and length of the fruit in $1^{\text {st }}$ hand and the number of fruits, the mass of $4^{\text {th }}$ hand and the fruit diameter of the last hand were higher in Period 2 (Table 1). Other characteristics were not influenced by the bunch formation period. Part of these differences are due to climate conditions during the bunch growth, which in Period 1 had average minimum and maximum temperatures, accumulated rainfall and relative humidity, respectively, $14.6^{\circ} \mathrm{C}, 24.3^{\circ} \mathrm{C}$, and $465,3 \mathrm{~mm}$ $79.8 \%$, while in the Period 2, was of $21.9^{\circ} \mathrm{C}, 32.2^{\circ} \mathrm{C}$ $75.0 \%$ and $426,0 \mathrm{~mm}$. However, there was no difference in the total radiation between periods, which had an average value of $1,86 \mathrm{GJ} \mathrm{m} \mathrm{m}^{-2}$. Part are due to climate conditions before flowering, which in the Period 2 was the late spring and early summer, while in Period 1, the end of summer and early autumn, which influenced the pseudo stem perimeter, number of hands and number of fruits per hand. The most appropriate conditions before the Period 2, resulted in plants with higher pseudo stem perimeter and bunches with greater number of hands, which favored the accumulation of

Table 1 - Effect of defoliation in the yield and fruit quality of the banana 'Nanica', in function of the bunch formation period. Registro, SP.

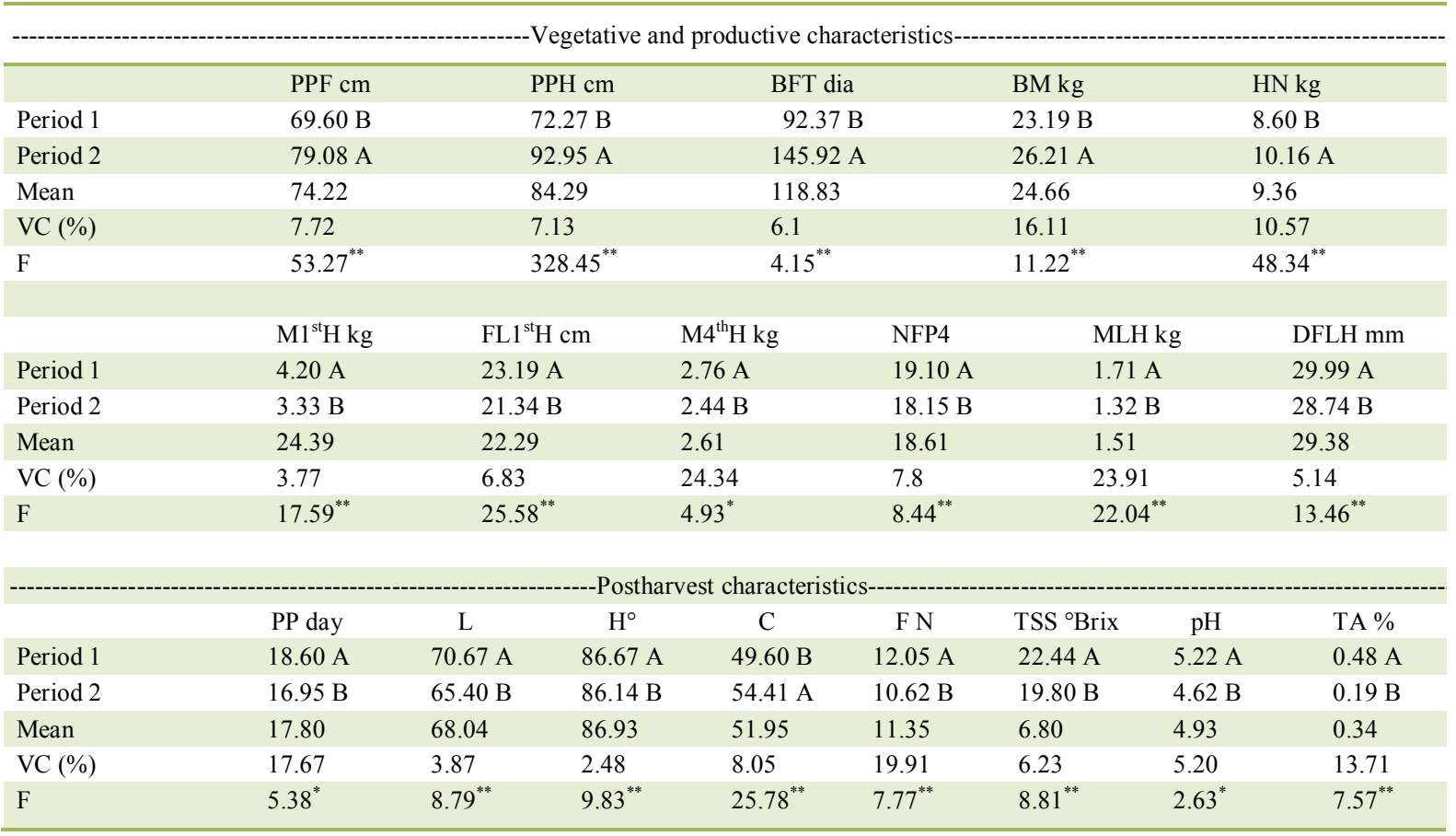

Pseudostem perimeter at flowering (PPF), pseudostem perimeter at harvest (PPH), bunch filling time (BFT), bunch mass (BM), number of hands $(\mathrm{NH})$, mass of $1^{\text {st }}$ hand $\left(\mathrm{M} 1^{\text {st }} \mathrm{H}\right)$, fruit length in $1^{\text {st }}$ hand $\left(\mathrm{FL} 1^{\text {st }} \mathrm{H}\right)$, mass of the $4^{\text {th }}$ hand $\left(\mathrm{M} 4^{\text {th }} \mathrm{H}\right)$, fruit length in the $4^{\text {th }}$ hand $\left(\mathrm{FL} 4^{\text {th }} \mathrm{H}\right)$, fruits number of $4^{\text {th }}$ hand $\left(\mathrm{FN} 4^{\text {th }} \mathrm{H}\right)$, postharvest period $(\mathrm{PP})$, luminosity $(\mathrm{L})$, angle Hue $\left(\mathrm{H}^{\mathrm{o}}\right)$, chromaticity $(\mathrm{C})$, firmness $(\mathrm{F})$, total soluble solid (TSS), $\mathrm{pH}$ and titratable acidity (TA). Period 1, flowering in 15/04/2013 and period 2, flowering in 07/01/2014. ${ }^{* *} \mathrm{P}<0.01 ;{ }^{*}, \mathrm{P}<0.05 ;{ }^{* *} ;{ }^{\mathrm{NS}}$, not significant by $\mathrm{F}$ test; $\mathrm{VC}$, variation coefficient. 
biomass in the bunch as a whole, but smaller mass in hands, because of the lower number or size fruits. The higher bunch filling time in Period 2, probably due to greater number of hands (sink) since the radiation was the same in both periods.
The leaf number at flowering affected pseudostem perimeter, which was lower in plants with 8 and 9 leaves (Figure 1A). Number of leaves in the harvest increased with the number of leaves maintained at flowering varying from 4.4 in plants with 6 leaves to

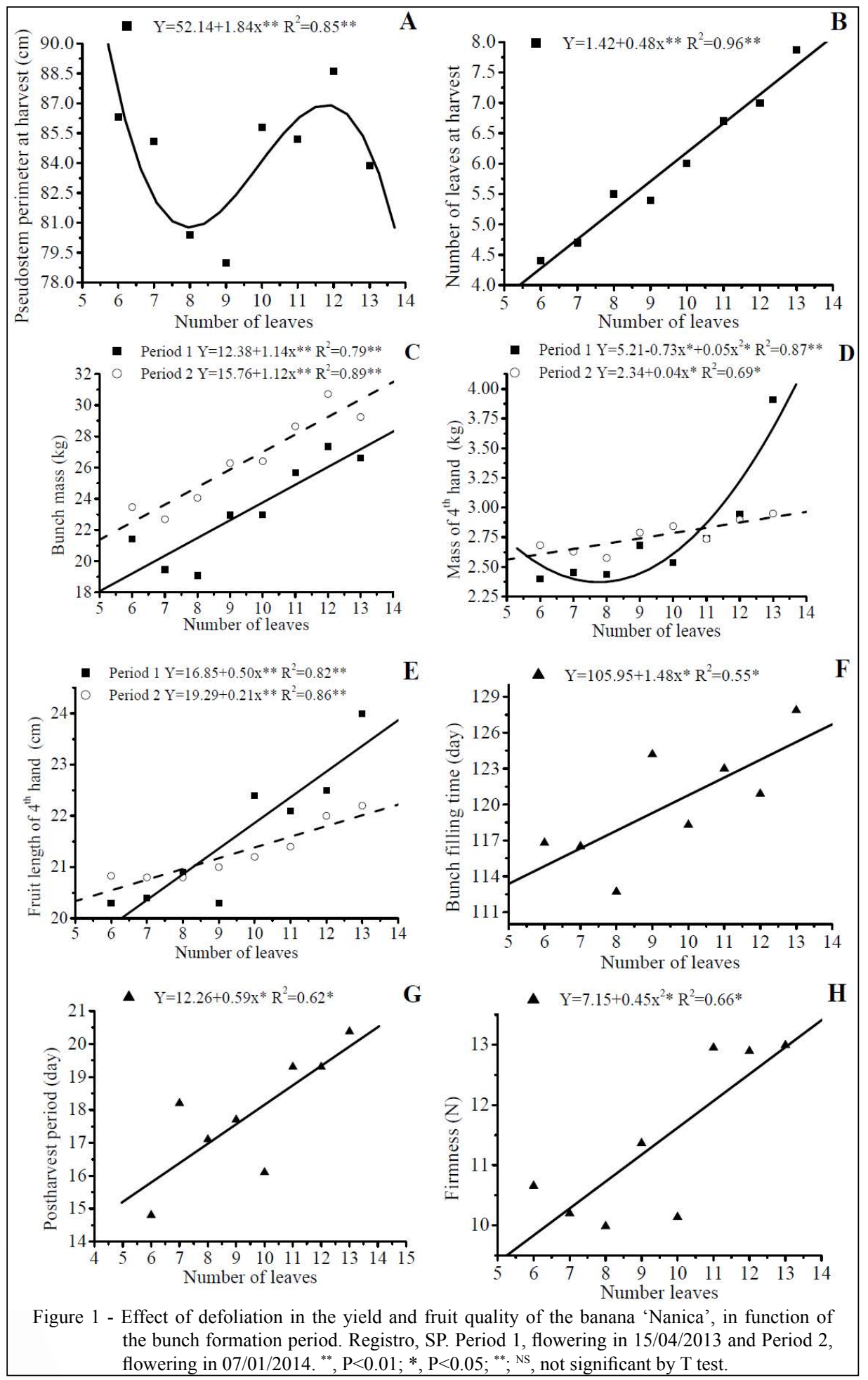

Ciência Rural, v.47, n.1, 2017. 
7.9 in plants with 13 leaves (Figure 1B). RAMIREZ et al. (2008) observed that banana plant 'Nanica' kept with 7,9, 11 and 13 leaves or without defoliation at flowering exhibited between 6 and 7 leaves at harvest.

The number of leaves in flowering influenced linearly the mass of the bunch (Figure 1C), that in Period 1 ranged from 19 to $27 \mathrm{~kg}$ plant ${ }^{-1}$ and Period 2, 22-30kg plant ${ }^{-1}$. Positive correlations were found between the number of leaves at harvest and the mass of the bunch (Period 1: $\mathrm{Y}=9.78+2.26 \mathrm{x} * * \mathrm{R}^{2}=0.72 * *, \mathrm{r}=0.85^{* *}$ and Period 2: $\left.\mathrm{Y}=13.15+2.23 \mathrm{x} * * \quad \mathrm{R}^{2}=0.81 * *, \mathrm{r}=0.91 * *\right)$. In Period 1 , the mass of $4^{\text {th }}$ hand increased linearly with the number of leaves, whereas in the Period 2, increased in a quadratic way (Figure 1D). In both Periods, the length of the fruit of $4^{\text {th }}$ hand increased with the number of leaves (Figure 1E). Thus, the accumulation of mass of the bunch with increasing number of leaves occurred concomitantly with the increase of the mass of the fruit of $4^{\text {th }}$ hand, which was the result of increased fruit size. In tropical conditions, the defoliation of banana 'Nanica' did not affect bunch mass and fruit size (VARGAS et al., 2009; GONZÁLEZ et al., 2012); however, in subtropical, there was a reduction in plants with less than 10 leaves (DANIELLS et al., 1994). Regardless of period, the bunch filling time increased with the number of leaves, but with a variation of only 15 days between plants with higher and lower number of leaves (Figure 1F). Such response reflects the correlation between the filling time and mass bunch (sink) in Period $1(\mathrm{Y}=$ $\left.38.42+0.51 \mathrm{x}^{* *} \mathrm{R}^{2}=0.64, \mathrm{r}=0.80^{* *}\right)$ and Period 2 $\left(\mathrm{Y}=-24.92+0.43 \mathrm{x} * \mathrm{R}^{2}=0.52 * \mathrm{r}=0.72 *\right)$.

The postharvest period was higher in fruits formed in the Period 1 than in Period 2 (Table 1), possibly due to differences in metabolism resulting from the temperature during the formation of the bunch, which were more moderate in Period 1 , requiring more time for ripening. The lower brightness and chromaticity in Period 1, arises from the peel browning caused by the cold temperatures below $12^{\circ} \mathrm{C}$. However, the Hue angle that indicates the color yellow fruit was higher in Period 1 than in Period 2 (Table 1) as the firmness, soluble solids, $\mathrm{pH}$ and titratable acidity. The higher soluble solids in Period 1, which mainly express the free sugars, may be related to acclimation to low temperature.

The higher number of leaves at flowering increased postharvest period (Figure $1 \mathrm{G}$ ), and the firmness of the ripe fruit (Figure 1H). This indicated that the increased availability of assimilates due to the higher number of leaves promoted the highest growth in fruit size (Figure 1E) and extended the bunch filling period (Figure 1F) as a consequence of physiological maturity, resulting in longer time to complete ripening (Figure 1G). DANIELLS et al. (1994) and RAMIREZ et al. (2008) reported no effect of defoliation on postharvest period, while GONZÁLEZ et al. (2012) reported no effect on physical-chemical characteristic of the fruit.

Defoliation is suggested only for nonfunctional leaves, as well as the maintenance of at least 10 plant $^{-1}$ to achieve the average bunch mass of $26.5 \mathrm{~kg}$ (Figure 1C) and yield of 42.4ton ha-1, above the national average yield of 23.8ton $\mathrm{ha}^{-1}$ (AGRIANUAL, 2016).

\section{ACKNOWLEDGEMENTS}

To Fundação de Amparo à Pesquisa do Estado de São Paulo (FAPESP) (2014/02975-1) for the research grant given to the second author.

\section{REFERENCES}

AGRIANUAL. Anuário da Agricultura Brasileira. Available fom: <http://www.agrianual.com.br>. Accessed: May 24, 2016.

AOAC (ASSOCIATION OF OFFICIAL ANALYTICAL CHEMISTS). Official methods of analysis of the association of official agriculture chemistry. 18.ed. Arlington, 2005. 2590p.

CHILLET, M. et al. Necrotic leaf removal, a key component of integrated management of Mycospaerella leaf spot diseases to improve the quality of banana: the case of Sigatoka disease. Fruits, v.68, n.4, p.271-277, 2012. Available from: $<\mathrm{http}: / / \mathrm{www}$. fruits-journal.org/articles/fruits/pdf/2013/04/fruits 130073. pdf $>$. Accessed: Jul. 05, 2015. doi: 10.1051/fruits/2013073.

DANIELLS, J.W. et al. Effect of bunch trimming and leaf removal at flowering on maturity bronzing, yield, and other aspects of fruit quality of bananas in North Queensland. Australian Journal of Experimental Agriculture, v.34, n.2, p.259-265, 1994. Available from: <http://www.publish.csiro.au/?act=view file\&file_id=EA9940259.pdf $>$. Accessed: Jul. 05, 2015.

GONZÁLEZ, C.R. et al. Effect of number of functional leaves at flowering on yield of banana 'Grand Naine' (Musa AAA Simmonds). Revista Facultad Nacional de Agronomía Medellín, v.65, n.2, p.6591-6597, 2012. Available from: <http:// www.scielo.org.co/pdf/rfnam/v65n2/v65n2a03.pdf $>$. Accessed: Sept. 12, 2015.

MORAES, W.S. et al. Dominância da Sigatoka-negra em bananais do Vale do Ribeira. Fitopatologia Brasileira, v.30, p.19, 2005.

RAMÍREZ, M. et al. Leaf pruning intensities at flowering of banana (Musa AAA, cv. 'Grande Naine') did not influence fruit green and 
yellow life and quality. Scientia Horticulturae, v.115, n.4, p.319322, 2008. Available from: $<\mathrm{http}: / / \mathrm{www}$. sciencedirect.com/science/ article/pii/S0304423807003494>. Accessed: Sept. 12, 2015. doi: 10.1016/j.scienta.2007.10.014.

TRESSLER, D.K.; JOSLYN, M.A. Fruit and vegetable juice: processing technology. Westport: Avi Publishing Company. 1961. 1028p.
VARGAS, A. et al. Effect of leaf pruning at flower emergence of banana plants (Musa AAA) on fruit yield and black Sigatoka (Mycosphaerella fijiensis) disease. International Journal of Pest Management, v.55, n.1, p.19-25, 2009. Available from: $<$ http://www.tandfonline.com/doi/pdf/10.1080/0967087080 2450219?needAccess=true $>$. Accessed: Sept. 12, 2015. doi: $10.1080 / 09670870802450219$. 